\title{
THE HAPPINESS OF WOMEN WEARING FACE-VEIL
}

\author{
Amalia Ridha Sudirman, Rena Latifa \\ UIN Syarif Hidayatullah Jakarta, Indonesia \\ Email: amalia.rsn@gmail.com
}

\begin{abstract}
Around 2017 women wearing face-veil has been increase in Indonesia. Nevertheless, high perceptions and behavioral discrimination are still experienced by most face-veiled women in their daily social life. This can be harming happiness which is an important psychological condition for every individual furthermore. Through sample of 199 participants of early adult women who wearing face-veil from big cities area, OHQ scale (Hills \& Argyle, 2002) was used to measure happiness, MMS scale (Dasti \& Sitwat, 2014) for Islamic spirituality, and IPC scale (Levenson, 1981) for locus of control. Validity test is done firstly by CFA method and Lisrel software. Then a multiple analysis method (MRA) was carried out to test the effect through SPSS software. Analysis results of this study indicated there is a significant effect of Islamic spirituality and locus of control towards happiness of face-veiled women in big cities, with statistical value at $55.1 \%$. Whereas regression coefficient results showed that four sub-variables that contributed significantly are self discipline, feelings connectedness with Allah, meanness-generosity, and internal locus. The author hopes that the implications of the research results will be reviewed and developed in further research by further examining what factors are the fourth factors and deepening the information on things that will increase happiness, especially in certain groups, such as women wearing face-veil.
\end{abstract}

Keywords: Happiness of woman wearing face-veil; face-veiled women;

Abstrak. Sekitar tahun 2017 perempuan yang memakai cadar di Indonesia meningkat. Meski demikian, persepsi dan diskriminasi perilaku yang tinggi masih dialami oleh sebagian besar perempuan bercadar dalam kehidupan sosial sehari-hari. Hal ini dapat merusak kebahagiaan yang merupakan kondisi psikologis penting bagi setiap individu selanjutnya. Melalui 199 sampel partisipan wanita dewasa awal yang memakai cadar dari wilayah kota besar, skala OHQ (Hills \& Argyle, 2002) digunakan untuk mengukur kebahagiaan, skala MMS (Dasti \& Sitwat, 2014) untuk spiritualitas Islam, dan skala IPC. (Levenson, 1981) untuk lokus kendali. Uji validitas dilakukan terlebih dahulu dengan metode CFA dan software Lisrel. Kemudian dilakukan metode analisis berganda (MRA) untuk menguji pengarub tersebut melalui software SPSS. Hasil analisis penelitian ini menunjukkan babwa terdapat pengaruh yang signifikan antara spiritualitas Islam dan locus of control terhadap kebahagiaan perempuan bercadar di kota-kota besar, dengan nilai statistik sebesar 55,1\%. Sedangkan hasil koefisien regresi menunjuke.ean bahwa empat sub variabel yang memberikan kontribusi signifikan adalah disiplin diri, perasaan keterbubungan dengan Allab SWT, sifat-sifat murah hati, dan lokus internal. Penulis berbarap implikasi dari hasil penelitian di kaji kembali dan dikembangkan pada penelitian selanjutnya dengan meneliti lebih lanjut fator-faktor apa saja yang menjadi penyebab keempat variabel ini serta memperdalam informasi hal-hal yang akan meningkatkan kebahagiaan terutama pada kelompok tertentu, seperti wanita bercadar.

Kata Kunci: Kebahagiaan wanita berjcadar; wanita bercadar;

Permalink/DOI: https://doi.org/10.15408/mimbar.v37i2.18912 


\section{Introduction}

In the last few years, woman who wear face-veil or niqab or purdah is something that is not too odd to be found in society. Women wearing face-veil have increased, especially in some big cities in Indonesia such as Aceh, Pekanbaru, Jakarta, Bandung, and Poso (Novri, 2016). As it is indicated by the establishment of a community named Niqab Squad, which is accommodating all of women with faceveil (Yulistara, 2017b).

Evidently when the first gathering held, there were more than 500 face-veiled-women come from big cities and surrounding areas (Yulistara, 2017a). In addition, the increasing in phenomena is also marked by its impact on the design of clothing orders. Muslim wedding dresses with face-veil reportedly increased in order around 2017 even there were rarely ordering with these designs before (Yulistara, 2017b).

Face-veil is a form of clothing that covers the entire of face by only showing eyes or area around eyes (Ratri, 2011). There are several different opinions (kbilafiyah) among scholars or ulama regarding the law of wearing face-veil. Some stated it is wajib or obligatory (Shalih, 2001) whereas others stated it as a mustahabb or recommended (Albani, 2016) according to syariab or Islamic law about woman wearing face-veil.

In response to these issues, majority of scholars consider conditions and circumstances to establish its law for a woman. Hidayat (2018) explained that woman individually can choose which law should be referred to by considering some virtues of its benefit (the law advocating veil) or an obstacle that may be encountered when taking these virtues, so they can choose a lighter law that is musahabbah or unprioritazing to wear a face-veil.

But Amanda and Mardianto (2014) revealed even majority of population in Indonesia is Islamic believer, women wearing face-veil still not fully accepted by public in general. Among threats that are still faced by women wearing face-veil are stigma of societies that identify wearing a face-veil with people of radicalism and terrorism (Nirawati, 2016; Muliono, 2017; Rahman \& Syafiq, 2017). One example occurs towards some women wearing face-veil in one of sub-district in Riau (Novri, 2016).

Then another threat are public service discrimination (Amanda \& Mardianto, 2014). As a matter of fact about disallowance on waering a face-veil involves one of private educational institution in Tangerang (Hambali, 2017a).

Some of these disallowance state if wearing a face-veil makes a barriers to communication (Hanurawan, 2010). Because individuals will instinctively have more difficulty recognizing a closed face and emotion (Kret \& Fischer, 2017). Especially women who only show eyes with transparency of 20\% will get a greater tendency to be attributed by angry and fearful emotions by others (Kret \& de Gelder, 2012).

This makes people tend to give more negative perceptions to individuals whose dresses more covered (Everett, et al., 2015). The greater this negative perception affects the greater negative attitude 
of people towards woman who cover her face likely veiled women (Fischer, Gillebaart, Rotteveel, Becker, \& Vilek, 2012).

Existence of indifference prejudices to behavioral discrimination from some people makes women wearing face-veil feel disturbed, uncomfortable, and depressed (Rahman \& Syafiq, 2017) as far as feeling threatened (Hambali, 2017b). All of these restless psychological conditions can lead women to stress (Taylor, Peplau, \& Sears, 2009).

Threats of personal freedom to stressful pressures can affect a decrease in the level of happiness of individuals (Alavi, 2007). Good social contact which is the main essence of happiness in women will be disrupted women (Diener \& Biswas-Diener, 2008).

Whereas happiness is an important aspect for every individual, as it is no exception for women wearing veil. Happiness is the thing that every person dreaming more than wealth and popularity (Boniwell, 2008). Aristotle through his observations stated that happiness is the whole and the end of goal of individual's existence (in Lopez, 2008). Happiness is seen as a value that needs to be owned and a goal that needs to be achieved universally (Altiner, 2015).

From the breadth of views on happiness study, there are also various formulations comes from psychologists. Among them are Seligman with authentic happiness (Lopez, 2009) or Diener with subjective well-being (Diener \& Biswas-Diener, 2008). Hills and Argyle (2002) define happiness as when women wearing face-veil are able to feel and receive high life satisfaction and high positive emotion and feel low negative emotions at same time.

Happiness is not just a common dream, but a psychological state that brings significant benefits and influences in life. They are improving physical health, enhancement quality of mental health (Boniwell, 2008), help in dealing with various problem solving and find the right answer to make a decision (in Snyder \& Lopez, 2007), and including individual success (Lyubomirsky, King \& Diener, 2005).

In sum, Martin (in Alavi, 2007) states if individual will function better, mentally and physically, when individuals feel happy. Becoming more passionate, more successful, more creative, healthier and live longer. A lot of meaningful benefits by having happiness, making happiness as an important emotion to be felt and maintained for each individual's stability.

To determine exactly what factors play a role for women wearing face-veil to increase happiness, a preliminary study (pilot study) was conducted earlier. Through short interview method, results show that some caused are due to feeling of closeness with God and one's perception toward things happened.

Feeling of closeness with God is ones reflection of religious values inherent among women wearing face-veil. In psychological term, this is called condition of spirituality. This spirituality is more exclusively refering to Islamic spirituality, where the feeling of closeness is shown to God, namely Allah SWT, which is core part of teachings of Islam.

Through face-veil she wearing, women hope for rewards from Rido Allah, to obtain salvation on the Last Day or akhirah. Belief in hereafter as an eternal happiness has helped many individuals to find 
purpose of life and to maintain moral courage and kindness when individuals face difficulties and hardships (Alavi, 2007). According to Diener and Biswas- Diener (2008), religion is indeed the center of the lives of billions people, so individuals will tend to use clothing and jewelry related to their religion, likely wearing face-veil as Islamic believer.

Spirituality help people integrating their wants and needs, then substantially set to become a life destination (Franklin, 2010). Because basically all individuals need something above (outside) themselves to be believed, something that can be the goal of life and death (Myers in Franklin, 2010). So that individuals who are spiritualists are found to more demonstrate welfare and higher happiness of than non-spiritualists (Diener \& Biswas-Diener, 2008).

Besides spiritual factor, another factor that plays a role in influencing happiness is one's perception towards things happened or likely to be called as locus of control (Argyle in Pannells \& Claxton, 2008). Locus of control is considered as one of cognitive aspects of an individual's personality related to his thinking style so that these characteristics can be manipulated to enhance various emotions, including happiness (Pannells \& Claxton, 2008). Individuals with internal locus' tendency believe what regulates their behavior at all times is themselves. While individuals with external locus' tendency believe situations occur to him and all their behavior are part of fate or caused by encouragement from others (Rotter in Pannells \& Claxton, 2008).

Therefore individuals with internal locus tendencies have more significant levels of happiness (Devin et al., 2012). Because these individuals tend to focus more on finding new actions that can be done when things do not match their expectations take place, rather than spending time blaming surroundings (Devin et al., 2012). They will remember more positive things in life and try to repress their failures.

This is contrary to individuals with external locus tendencies who tend to find it difficult to make changes because they see things are influenced by external factors, such as other people or luck. So they do not have ability to change their lives (Pannells \& Claxton, 2008). Making they focus to depend his happiness from outside likely to cause individuals to feel unhappy.

Based on these theories about happiness, benefits and factors causing it as well as condition of field that do not match expectationshave experienced by face-veiled women, we wants to examine more about how are condition of happiness on women wearing face-veil, how much level of happiness is felt and how much spiritual and locus of control will play a role in effecting happiness on women wearing face-veil.

\section{Research Methods}

\section{Demographic information}

Participants in this study were women who wear a face-veil in their daily lives. They are in the early and middle adulthood (18 - 45 years) as well as lives in big cities. Total participants in this study were 199 participants.

\section{Measurements}


Happiness scale. Adapted from OHQ scale (Oxford Happiness Questionnaire) which developed by Hills and Argyle (2002). Consists of 6 dimensions with 29 items. Each item on this scale contains six alternative answers. Participants were asked to choose one alternative answer from each of items that most describing or explaining what he felt during previous week before, including the day of answer was taken directly (Liaghatdar, et al., 2008). Reliability of OHQ internal consistency in this study has been reported with Chi-Square value $=290.01, \mathrm{df}=255, \mathrm{P}$-value $=0.06507$, and $\mathrm{RMSEA}=0.026$.

Islamic spiritual scale. Adapted from MMS scale (Multidimensional Measure of Islamic Spirituality) which firstly developed by Dasti and Sitwat (2014). This measuring instrument is considered to be quite comprehensive and different from other Islamic orientation measurement tools because it contains eight dimensions that are quite specific in explaining values of Islamic teachings. Contains 8 dimensions with 75 items. But in this study, only 46 items were taken after going through the process of adaptation with expert judgments.

Locus of control scale. Adapted from IPC Scale (Internal, Powerful Others, and Chance) which developed by Levenson (1981). This measurement tool is multidimensional and uses a Likert scale making it easier to cut the value of each type of locus of control. The items are more specific and not as common as Rotter scale (1966), and are considered to have low social desirability or low bias effect (Halpert \& Hill, 2011).

\section{Result And Analysis}

The following is an overview of the overall research participants:

Table 4.1: General description of research participants

\begin{tabular}{ccc}
\hline Sampel Penelitian & Frekuensi & (\%) \\
\hline Durasi Penggunaan Cadar & & \\
$<$ l tahun & 73 & 36,7 \\
$\mathbf{1}-\mathbf{3}$ tahun & 107 & 53,8 \\
$>$ > tahun & 19 & 9,5 \\
Tingkat Pendidikan Akhir & & \\
SD/sederajat & 1 & 0,5 \\
SMP/sederajat & 4 & 2 \\
SMA/sederajat & 124 & 62,3 \\
Diploma & 20 & 10,1 \\
Strata 1 & 50 & 25,1 \\
Status Pernikahan & & \\
Telah Menikah & 61 & 30,7 \\
Belum Menikah & 138 & 69,3 \\
Status Pekerjaan & & \\
Telah Bekerja & 88 & 44,2 \\
Belum Bekerja & 111 & 55,8 \\
& & \\
Usia & 147 & 73,9 \\
18 - 24 tahun & 40 & 20,1 \\
25 - 34 tahun & 12 & 6 \\
35 - awal 40 tahun & & \\
Wilayah Tinggal & 79 & 39,7 \\
Jakarta & 27 & 13,6 \\
Bogor & 35 & 17,6 \\
Depok & 38 & 19,1 \\
Tangerang & 20 & 10,1 \\
Bekasi & & \\
\hline & & \\
\hline
\end{tabular}


$\mathbf{0 . 2 1 3} \boldsymbol{*}$ meanness- generosity +0.96 tolerance-intolerance -0.035 Islamic practices $+\mathbf{0 . 2 2 6} \boldsymbol{*}$ internal 0.068 powerful other- 0.081 chance $+\mathrm{E}$.

To find out a significant regression coefficient, we can see it in the column of significant values. If sig. $<0.05$, then regression coefficient has a significant effect on the dependent variable. Following is explanation of all regression coefficients of each independent variable: a) Regression coefficient value in self- discipline variable is at $+0,285$ with significance value of 0,000 (Sig. $\mathrm{P}<0,05$ ). Then the null hypothesis is rejected, that is to say regression coefficient of self-discipline variable has a significant effect on happiness. Positive coefficient value means that the higher individual's tendency to behave in form of self- discipline, the higher of happiness she has; b) Regression coefficient value in quest and search for divinity variable is at $+0,110$ with significance value of 0,246 (Sig. P> 0,05). Then the null hypothesis is accepted, that is to say no significant effect of quest and search for divinity variable on happiness; c) Regression coefficient value in anger and expansive behavior variable is at -0.062 with significance value of 0.402 (Sig. P> 0.05). Then the null hypothesis is accepted, that is to say no significant effect of anger and expansive behavior variable on happiness; d) Regression coefficient value in self-aggrandizement variable is at -0.002 with significance value of 0.979 (Sig. P > 0.05). Then the null hypothesis is accepted, that is to say no significant effect of self-aggrandizement variable on happiness; e) Regression coefficient value in feelings of connectedness with Allah variable is at +0.218 with significance value of 0.010 (Sig. $\mathrm{P}<0.05$ ). Then the null hypothesis is rejected, that is to say regression coefficient of feelings of connectedness with Allah variable has a significant effect on happiness. Positive coefficient value means that the higher individual's tendency to feel connectedness relationship with Allah, the higher of happiness she has; f) Regression coefficient value in meanness-generosity variable is at +0.213 with significance value of 0.001 (Sig. $\mathrm{P}<0.05$ ). Then the null hypothesis is rejected, that is to say regression coefficient of meanness-generosity variable has a significant effect on happiness. Positive coefficient value means that the higher individual's tendency to behave generously towards others, the higher of happiness she has;

g) Regression coefficient value in tolerance- intolerance variable is at $+0,096$ with significance value of 0,207 (Sig. P>0,05). Then the null hypothesis is accepted, that is to say no significant effect of tolerance-intolerance variable on happiness; $\mathrm{h}$ ) Regression coefficient value of Islamic practices variable is at -0.035 with significance value of 0.691 (Sig. $\mathrm{P}>0.05$ ). Then the null hypothesis is accepted, that is to say no significant effect of Islamic practices variable on happiness; i) Regression coefficient value of locus of internal variable is at +0.226 with significance value of 0.000 (Sig. $\mathrm{P}<0.05$ ). Then the null hypothesis is rejected, that is to say regression coefficient of locus of internal variable has a significant effect on happiness. Positive coefficient value means that the higher tendency of individual who have internal locus of control, the higher of happiness she has; j) Regression coefficient value in locus of powerful others variable is at -0.068 with significance value of 0.257 (Sig. P> 0.05). Then the null hypothesis is accepted, that is to say no significant effect of locus of powerful others variable on happiness; k) Regression coefficient value in locus of chance variable is at -0.081 with significance value of 0.253 (Sig. P> 0.05). Then the null hypothesis is accepted, that is to say no significant effect of locus of chance variable on happiness. 


\section{Conclussion}

According to Hofmann et al. (2013) individuals with high levels of disciplinary behavior will be much better at controlling their daily and routine activities so that they avoid problems or difficulties that might occur. Regularity in every routine helps an individual to achieve various goals in his life so that he can feel life satisfaction and help her improve positive emotions.

According to Dasti and Sitwat (2014) this may also be motivated by one of manifestation of teachings in Islam, that is spiritual values, where individuals believe if Allah loves disciplined actions regardless of how small itsmeaning (Mawlud in Dasti \& Sitwat, 2014). The teachings in Islam which emphasize that life lived by each individual is essentially a capital for him to achieve lasting happiness. This happiness alone will only be achieved if individuals are disciplined in their daily lives, such as forming routine and aimed activities (Dasti \& Sitwat, 2014).

High discipline behavior will direct individuals to resist impulsive temptations and work according to long-term goals. Discipline will cause individuals to sacrifice a variety of momentary pleasures but facilitate them in achieving more important goals (Garbunovs, Kapenieks, \& Cakula, 2016). Success in achieving every more important goal is what is predicted to be the cause of a steady increase in happiness, not merely a moment of pleasure.

Then another variable that has a significant positive effect on happiness is feeling of connectedness with Allah of Islamic spirituality variable. This means that women wearing face-veil who have the higher feeling of being connected with Allah, the higher level of happiness they have. Basically, in Islamic spirituality, individual relationships with Allah are based on His Mercy. Islamic believers believe Allah as his one and only God, believe in His Destiny and Determination, and be optimistic about each of these provisions (Khodayarifard, et al., 2016). This optimistic attitude and hope for His Mercy leads individuals to happiness and decreases anxiety (Khodayarifard, et al., 2016).

Beck (in Rashidi et al., 2016) states that individuals who have a high relationship with God (secure attachment) will feel more happiness. Whereas in a different study by Bradshaw et al. (2010) found that individuals with a low relationship with God significantly influence high stress levels. Both of these studies explain if relationship of feeling connected to God is same as feeling of being secure from parents. Individuals who have high and safe feeling of attachment to their God tend to foster composure and tranquility when facing whether conflicts or challenges. This positive attitude makes individuals happy regardless of whatsoever conditions they experience, they tend to look for positive ways to respond to these conditions.

Another variable that have positive significance effect on happiness is meanness- generosity behavior of Islamic spirituality variable. This means that the higher generous behavior of women wearing face-veil, the higher happiness they have. In connection with strong beliefs (internal belief system) of God's mercy making individuals more motivated to act compassionate (generous) towards others.

Through various forms of generosity behavior (such as helping to solve problems, alleviating sesame affairs) will add meaningful feelings to individual and then increase his happiness (Khodayarifard, et al., 2016). Furthermore, by acting as an altruist and volunteer (next level of generous 
behavior) will further increase meaningfulness in life and making individuals more prosperous and happy twice as the others (Holder, et al., 2010; Alavi, 2007).

Then the last variable in this study that have positive significant effect on happiness is internal locus of locus of control variable. That is to say the higher women wearing face-veil has tendency of internal locus, the higher happiness they have. Individuals with a high tendency of internal locus will try to repress failures that have been experienced and remember successes that have been obtained (Ramezani \& Gholtash, 2015). Because individuals tend to conclude if their happiness and well-being can be maximized by mobilizing the best efforts that can be done.

Individuals with a high degree of internal locus tendencies believe that they themselves are responsible for their own behavior and every decision (Devin et al., 2012). Through this style of thinking, individuals tend not to spend time lamenting fact that something like an event is beyond expectations. Rather, they tend to look for opportunities and actions that can reverse the situation. This style of thinking manipulates negative emotions that were initially felt to be positive emotions, tranquility, and happiness in individuals (Pannells \& Claxton, 2008).

\section{CONCLUSSION}

Focus of this research is to find out factors that influence happiness of women wearing face-veil in big cities. Based on result of this study showed happiness of majority of women wearing face-veil are only at moderate level, which is as much as $68.3 \%$. While women wearing face-veil who have high and low levels of happiness are not much different, specifically as much as $16.1 \%$ and $15.6 \%$.

Through results of regression coefficients in this study, showing that self-discipline of Islamic spirituality variable positively has the greatest and most significant influence on happiness. The higher discipline behavior possessed by face-veiled women in big cities, the higher level of happiness they have. Individuals who uphold high self-discipline behaviors, such as in demands of worship, eating, sleeping, being persistent, eager to achieve goals, etc., tend to have good fortitude, perseverance, and self-control. The author hopes that the implications of the research results will be reviewed and developed in further research by further examining what factors are the fourth factors and deepening the information on things that will increase happiness, especially in certain groups, such as women wearing face-veil

\section{REFERENCES}

Ahmad, M., \& Khan, S., 2015. A model of spirituality for ageing muslims. Journal of Religion Health. DOI 10.1007/s10943- 015-0039-0.

Alavi, H. R., 2007. Correlatives of happiness in the university students of Iran: A religious approach. Journal of Religion and Health, 46 (4), 480-499. DOI 10.1007/s10943-

007-9115-4.

Albani, S.M.N., 2016. Jilbab wanita muslimah: Menurut qur'an dan sunnah. Solo: At-tibyan.

Altiner, S., 2015. Happiness. Thesis. Holland: University of Leiden. 
Amanda, R., Mardianto., 2014. Hubungan antara prasangka masyarakat terhadap muslimah bercadar dengan jarak sosial. Jurnal RAP UNP, 5 (1), 72-81.

Boniwell, I., 2008. What is happiness and subjective well-being? +11 interesting facts about happiness. Dikutip 2 Januari 2018, dari Positive Psychology: http://positivepsychology.org.uk/happin ess-and-subjective-well-being/.

Bradshaw, M., Ellison, C.G., Marcum, J.P., 2010. Attachment to god, images of god, and psychological distress in a nationwide sample of Presbyterians. International Journal of Psychology and Religion, 20 (2), 130-147. DOI:10.1080/10508611003608049.

Dasti, R., Sitwat, A., 2014. Development of a multidimensional measure of islamic spirituality. Journal of Muslim Mental Health, $8 \quad$ (2), $\quad 47-67 . \quad$ http://dx.doi.org/10.3998/jmmh.103816 07.0008.204.

Devin, H. F., et al., 2012. The relationship between locus of control (internal- external) and happiness in pre- elementary teachers in iran. Procedia- Social and Behavioral Sciences, 46, 4169-4173. DOI: 10.1016/j.sbspro.2012.06.220.

Diener, E., Biswas-Diener, R., 2008. Happiness: Unlocking the mysteries of psychological wealth. Malden: Blackwell Publishing.

Everett, J. A., et al., 2015. Covered in stigma? The impact of differing levels of islamic head- covering on explicit and implicit biases toward muslim women. Journal of Applied Social Psychology, (45), 99104. DOI: $10.1111 /$ jasp.12278.

Fischer, A. H., Gillebaart, M., Rotteveel, M., Becker, D., Vilek, M., 2012. Veiled emotions: the effect of covered faces on emotion perception and attitudes. Social Psychological and Personality Science, 3 (3), 266-273. DOI: $10.1177 / 1948550611418534$.

Fitriani., Astuti, Y. D., 2012. Proses pengambilan keputusan untuk memakai cadar pada muslimah. Psikologika, 17 (2), 61-68.

Franklin, S. S., 2010. The psychology of happiness: A good human life. New York: Cambridge University Press.

Ghonimah., 2017. Identitas kultural mahasiswi bercadar di niniversitas islam negeri ampel Surabaya. Surabaya: FISIP UIN Sunan Ampel. Skripsi.

Halpert, R., Hill, R., 2011. The locus of control construct's various means of measurement: A researcher's guide to some of the more commonly used locus of control scales. NJ: Will to Power Press.

Hambali., 2017a. Wadub! Rektorat universitas pamulang larang mahasiswi kenakan cadar. Dikutip 17 Desember 2017, dari Okezone News:

https://news.okezone.com/read/2017/0 8/08/65/1752051/waduh-rektorat- universitas-pamulanglarang-mahasiswi- kenakan-cadar. 
Hambali., 2017b. Wadub! Rektor larang mahasiswa bercadar di kampus, mahasiswi: kami tertekan secara psikologis. Dikutip 17 Desember 2017, dari Okezone News: https://news.okezone.com/read/2017/0 8/09/65/17525/

77/waduh-rektor-larang-mahasiswa- bercadar-di-kampus-mahasiswi-kami- tertekan-secara-psikologis.

Hanurawan, F., 2010. Psikologi sosial: Suatu pengantar. Bandung: PT Remaja Rosdakarya.

Hidayat, A., 2018. Hukum cadar [video file]. Dikutip dari https://www.youtube.com/watch?v=64oSxgRapmc

Hills, P., Argyle, M., 2002. The oxford happiness questionnaire: A compact scale for the measurement of psychological well-being. Personality and Individual Differences, 33, 1073-1082.

Hofmann, W., et al., 2013. Yes, but are they happy? Effects of trait self-control on affective well-being and life satisfaction. Journal of Personality. DOI: 10.1111/jopy.12050.

Holder, M.D., Coleman, B., Wallace, J.M., 2010. Spirituality, religiousness, and happiness in children aged 8-12 years. Journal of Happiness Studies, 11, 131-150. DOI 10.1007/s10902-008-9126-1.

Hurlock, E. B., 2003. Psikologi perkembangan: Suatu pendekatan sepanjang rentang kehidupan, edisi ke-5. Jakarta: Erlangga.

Khodayarifard, M., et al., 2016. Positive psychology from islamic perspective. International Journal of Behavioral Science, 10 (2), 77-83.

Kret, M. E., de Gelder, B., 2012. Islamic headdress influences how emotion is recognized from the eyes. Frontiers in Psychology, 3 (110), 1-13. DOI: 10.3389/fpsyg.2012.00110.

Kret, M. E., Fischer, A. H., 2017. Recognition of facial expressions is moderated by islamic cues. Cognition and Emotion. DOI: 10.1080/02699931.2017.1330253.

Levenson, H., 1974. Activism and powerful others: Distinctions within the concept of internal-external control. Journal of personality Assessment, 38 (4), 377-383, DOI: 10.1080/00223891.1974.10119988.

Levenson, H., 1981. Differentiating among internality, powerful others, and chance. Dalam H.M. Lefcourt. Research with the Locus of Control Construct, hal. 15-63. New York: Academic Press.

Liaghatdar, M. J., Jafari, E., Abedi, M. R., Samiee, F., 2008. Reliability and validity of the oxford happiness inventory among university students in iran. The Spanish Journal of Psychology, 11 (1), 310-313.

Lopez, S. J., 2009. The encyclopedia of positive psychology. Malden: Blackwell Publishing Ltd.

Lyubomirsky, S., King, L., \& Diener, E., 2005. The benefits of frequent positive affect: Does happiness lead to success? Psychological Bulletin, 131 (6), 803-855, DOI 10.1037/0033-2909.131.6.803.

Muliono, S., 2017. Spirit cadar dan syndrome terorisme. Dipetik 20 Januari 2017, dari Fokus Islam: http:// fokusislam.com/8718-spirit- cadar-dan-syndrome-terorisme.html. 
Nirawati., 2016. Dinamika pengambilan keputusan mahasiswi bercadar di iain antasari Banjarmasin. Banjarmasin: Fakultas Ushuluddin dan Humaniora UIN Antasari. Skripsi.

Novri, M. S., 2016. Konstruksi makna cadar oleh wanita bercadar jamaah pengajian masjid umar bin khattab kelurahan delima kecamatan tampan pekanbaru. JOM FISIP , 3 (1), 1-12.

Nursalam., Syarifuddin., 2015. Persepsi masyarakat tentang perempuan bercadar. Jurnal Equilibrium Pendidikan Sosiologi, 3 (1), 116-125.

Pannells, T.C., Claxton, A.F., 2008. Happiness, creative ideation, and locus of control. Creativity Research Journal, 20 (1), 67-61, DOI: 10.1080/10400410701842029.

Puspanegara, V. A., 2016. Perilaku komunikasi perempuan muslim bercadar di kota Makassar: Studi fenomenologi. Makassar: FISIP Universitas Hasanudin. Skripsi.

Rahman, A.F., Syafiq, M., 2017. Motivasi, stigma, dan coping stigma pada perempuan bercadar. Jurnal Psikologi Teori dan Terapan, 7 (2), 103-115.

Ramezani, S.G., Gholtash, A., 2015. The relationship between happiness, self- control and locus of control. International Journal of Educational and Psychological Researches, 1 (2), 100-104. DOI: $10.4103 / 2395-2296.152222$.

Rashidi, M., Mousavi, F.S., Esmaeli, K., 2016. The relationship between styles of attachment to god and forgiveness and empathy among female students in the city of qom. Health, Spirituality and Medical Ethics, 3 (1), 18-24.

Ratri, L., 2011. Cadar, media, dan identitas perempuan muslim. FORUM, 39 (2), 29-37.

Rotter, J.B., 1966. Generalized expectancies for internal versus external control of reinforcement. Psychological Monographs: General and Applied, 80 (1), 609-637.

Shalih, M., 2001. Hukum Cadar. Solo: At-Tibyan.

Smet, B., 1994. Psikologi Kesehatan. Jakarta: Grasindo.

Snyder, C. R., Lopez, S. J., 2007. Positive psychology: The scientific and practical explorations of human strengths. California: Sage Publications.

Taylor, S. E., Peplau, L. A., Sears, D. O., 2009. Psikologi sosial, edisi ke-12. Jakarta: Prenadamedia Group.

Yulistara, A., 2017a. Mengenal niqab squad, komunitas para wanita bercadar di indonesia. Dikutip 17 Desember 2017, dari Wolipop Lifestyle: https:/m.detik.com/wolipop/read/2017/07/26/160355/3574754/1632/mengenal-niqab-squad komunitas-para-wanita- bercadar-di-indonesia.

Yulistara, A., 2017b. Fenomena baru, banyak hijabers yang ingin menikah pakai cadar di 2017. Dikutip 17 Desember 2017, dari Wolipop Lifestyle: 
MIMBAR Agama Budaya, 37 (2), 2020

https://m.detik.com/wolipop/read/2017/09/19/190239/3650279/1632/fenomena-barubanyak-hijabers-yang-ingin- menikah-pakai-cadar-di-2017. 